\title{
PERSPECTIVES ON POST-SOVIET
VIGILANTISM. Introduction
}

\section{Gilles Favarel-Garrigues, loulia Shukan}

Gilles Favarel-Garrigues is the issue's guest coeditor. He is CNRS Research Professor at Sciences Po CERI (Paris, France). Address for correspondence: Sciences Po CERI, 56 Rue Jacob, 75006 Paris, France. gilles.favarelgarrigues@sciencespo.fr.

Ioulia Shukan is the issue's guest coeditor. She is currently assistant professor in the Department of Slavic Studies at the University Paris Nanterre and research fellow in the Institute of Social Sciences of Politics. Address for correspondence: Université Paris Nanterre, 200 Avenue de la République, 92000 Nanterre, France. ioulia.shukan@parisnanterre.fr.

Moscow, 2012. About fifteen young men meet near a metro station in an outlying district to conduct an antidrug raid under the supervision of Arkadii Grichishkin, the leader of Molodezhnyi Antinarkoticheskii Spetsnaz (MAS, Youth Antidrug Commando). Some of them wearing hoodies, they complacently show the cameraman the weapons they carry: pickaxe handles, hammers, and an axe. ${ }^{1}$ Confident in themselves and in search of action, they move towards a kiosk selling cigarettes. One of them is filmed as he is buying some Spice-a popular synthetic drug, at that time not included on the official list of prohibited substances. When he gets back to the group and shows the Spice bag, the vigilantes cover the kiosk with stickers and graffiti ("Death sold here," "I kill children with impunity"), damage it with their weapons, and throw a smoke bomb inside in order to catch the seller. In this video, the justice makers leave the alleged drug dealer to the police, but in other cases they often add their own punishments once the "prey" is captured, molesting him, tying him to a pole, or splashing him with paint. In one of their videos the alleged drug dealer is covered not only with paint but also with feathers.

During the 2010s in post-Soviet societies, self-policing shows of this kind have spread on the internet and found a public audience among the young. Self-proclaimed justice makers do not fight with all offenders and deviants but select a particular type of target-alleged pedophiles and drug dealers, people drinking in public, shopkeepers selling expired products, dishonest public transportation inspectors, drivers violating parking rules in big cities, and so on. Despite their "niche" strategy, these groups share the same modus operandi. First, they use both physical and digital means of coercion against their targets: once they have caught their "prey," they not only prevent them from escaping, remind them of the law, eventually beat them, and/or call the police, but also film them and then edit and spread the videos on the

${ }^{1}$ See Konstantin Kuznetsov, “Molodezhnyi Antinarkoticheskii Spetsnaz. Reid," posted June 6, 2013. Video, 3:48. https://youtu.be/3CaaWLrZ6Qw. 
internet so as to expose and shame them on social networks. Using "visibility as a weapon" (Trottier 2017) in this way is a substantial part of the punishments selfproclaimed justice makers resort to. Second, their relationship to the law is generally paradoxical: they proclaim to defend legal norms but they break other rules to reach their goal. This is, for instance, the case for the above-mentioned Youth Antidrug Commando: in order to fight drug trafficking, they commit wrongful acts such as assaults and damage to property.

These forms of do-it-yourself justice making are akin to what is called vigilante justice in other contexts, even if the term does not exist in the Russian language. ${ }^{2}$ The Spanish term vigilante entered the English language during the nineteenth century to designate groups that, on the American frontier, took the law into their own hands in the place of institutions that were simply absent or at least seemed ineffective (Brown 1975). The term soon acquired a derogatory meaning, raising concerns and controversies in the United States. During the second half of the twentieth century, the term "vigilante" became increasingly used to designate do-it-yourself justice making in African contexts, especially in South Africa and Nigeria (Fourchard 2018). What was once an object of research reserved for US historians has become an anthropological category (Abrahams 1998). Today, as a controversial and "cheap form of law enforcement" (Sen and Pratten 2007:3), vigilantism is a global social phenomenon knowing no frontiers. The worldwide development and use of the internet have strengthened this trend towards the globalization of vigilantism, providing new resources and new opportunities to gather and spread information about socalled offenders (Trottier 2017), to recruit people for neighborhood patrols, and to demonstrate vigilante justice in action.

As a concept, vigilantism suffers from a "lack of conceptual clarity" (Moncada 2017:403). However, consensus regarding key elements contributes to our definition of this social practice. First, it is a collective form of action. Second, it is based on the use or threat of coercion. Third, this action targets people who have transgressed legal or moral norms. Fourth, the legitimacy of the action relies on reference to a third party, a larger community allegedly worrying for its security and preservation. This larger community may constitute the public, the audience that vigilantes intend to reach when they enforce the law. Fifth, a vigilante group has a limited life span but experiments with a sort of routine. More contested points in various definitions of vigilantism deal, on the one hand, with the allegedly "autonomous" formation of the groups and their reacting with "spontaneity" to perceived threats (Johnston 1996). Contrary to this belief, in many cases during US history vigilantes have had close ties with local economic elites, willing to defend an "established order"-for instance, protecting property against theft (Rosenbaum and Sederberg 1974). The issue of rewards is another source of discord. As Eduardo Moncada says, "the motivation for an act of vigilantism cannot be assumed to align neatly with the justification offered by its author(s)" (2017:408). Being a vigilante may provide an individual with econom-

2 As an exception, the nonprofit Foundation "Obshchestvennyi verdikt" (Public Verdict) has started to develop knowledge about Russian vigilantism since 2018. See its online project "Vigilanty": http://vigilant.myverdict.org/. 
ic and symbolic rewards, opening the way to profit-making strategies, to integration with law-enforcement agencies, as has occurred in Nigeria (Fourchard 2018), or to a political career.

As counterparts to vigilantes elsewhere, vigilantes in post-Soviet societies defend a variety of legal and moral norms. They enforce the ban on smoking or drinking in public places, as in the case of the Moscow-based Lev Protiv (Lion Versus) in Russia. They safeguard "traditional sexual relations," as claimed by the group Kyrk Choro (Forty Knights) in Kyrgyzstan, which organizes raids on nightclubs to apprehend and shame young women going out with foreigners and allegedly providing them with sexual services. ${ }^{3}$ They are involved in moral policing against alleged pedophiles, like members of the far-right group Scutul Social (Social Shield) in Moldova, who, inspired by their Russian counterparts from 0ccupy Pedophilia, used to hunt their "prey" by engaging in online conversations with them from a fake teenager's account, setting up an appointment with them in a private apartment, apprehending them there, harassing and shaming them, and occasionally beating them, before handing them over to the police. ${ }^{4}$ In Ingushetia vigilantes from the group Antisikhr fight a battle against sorcerers and their evil spells, or sihr in Arabic: they chase their targets, force themselves into their homes, masked and in military attire, and bring them to a remote place for a "courtesy" discussion. ${ }^{5}$ This list of supported causes can be complemented with numerous other examples. What are the particularities of post-Soviet vigilantes, compared to their counterparts in North America, Europe, Latin America, Asia, or Africa?

First, the development of post-Soviet vigilante justice has its own historical roots. It would be oversimplistic to draw a single line between peasant justice in tsarist Russia, the involvement of druzhiny in law enforcement in the post-Stalinist period, and contemporary forms of vigilante justice; however, it is important to realize that correspondences may be found between these social phenomena. When the Youth Antidrug Commando ties an alleged drug dealer to a pole and covers him with paint and feathers, or when Datsik - a former martial arts champion, neo-Nazi activist, and outrageous habitual offender-forces alleged prostitutes and their customers to walk nude in the streets to reach the police precinct, ${ }^{6}$ they are reminiscentintentionally or not-of shaming and lynching practices that were observed in nineteenth century peasant justice: vozhdenie and samosud (Frank 2000; Frierson 1987). And when Lev Protiv vigilantes remind those who consume alcohol in public places of the law, they echo law-enforcement practices of youth squad patrols

3 For an example of such an action, see Current Times, “Kirgizskie 'patrioty' zastavliaiut zhenshchin liubit' 'svoikh' ugrozami i poboiami," posted February 16, 2016. Video, 2:49. https://youtu. be/szp4JgSYP14.

4 For an account of a raid by Scutul Social, see "Kak v Kishineve loviat pedofilov na 'zhivtsa,"” Argumenty i fakty v Moldove, August 30, 2013. http://aif.md/kishinyovskaya-molodyozh-obyavilaboj-pedofilam/.

${ }^{5}$ See Olesia Gerasimenko, “'Smert' - 5,000 rublei': Pochemu v Ingushetii idet okhota na koldunov," BBS News Russia, March 21, 2019. https://www.bbc.com/russian/features-47628839.

${ }^{6}$ For an illustration of Datsik's methods, see Rossiia 24, "Natsionalist Datsik ustroil oblavu na bordeli Peterburga," posted May 18, 2016. Video, 2:47. https://youtu.be/XsKnNhB9sbY. 
(komsomol'skie spetsotriady) or of people's volunteer squads (dobrovol'nye narodnye druzhiny) in the late Soviet period.

However, the two decades separating Soviet druzhiny and 2010s vigilante groups are particularly relevant for the analysis of today's do-it-yourself justice making. The practices of the Youth Antidrug Commando should be compared, for instance, with other forms of private and/or citizens' involvement in drug repression since the late 1980s. Before he served as mayor of Yekaterinburg (2013-2018), Evgenii Roizman became locally famous for the crusade he launched against drugs as a businessman in the late 1990s. His methods were controversial, from rehabilitation techniques to the involvement of the Uralmash organized crime group in the surveillance and repression of customers and dealers (Roizman 2005). During the 2000s, punitive expeditions mostly targeted migrants. The Movement against Illegal Immigration (DPNI), for instance, organized raids in markets and workers' residences to flush out the nelegaly ("the illegals"). Far-right groups started to compete among themselves to "clean" the cities, "hunting," beating, and even killing their "prey" (Laryš and Mareš 2011; Shnirelman 2011). At the end of the decade, the spread of Russian internet (often called Runet) gave more visibility to these already existing practices: racist attacks and vigilante shows started to entertain an audience attracted by violent content. Before becoming famous as the most merciless "pedophile hunter" on the Runet in the early 2010s, Tesak was a leader of such skinhead gangs. Boasting about having killed migrants and already using digital resources to become popular, Tesak was sentenced to prison for the first time in 2009 for inciting racial hatred.

Second, the development of vigilante justice in the early 2010s took place in a context of sharpened distrust of police. Journalists, human rights activists, businessmen, and even political leaders have been denouncing the indifference, corruption, and violence of the police since glasnost (Gerber and Mendelson 2008). In Russia, after a decade of disparagement, harsh criticism both from the population and from political leaders, and institutional reorganization (Taylor 2011), a major reform of the Ministry of Internal Affairs was finally undertaken in 2011, but its implementation was quickly criticized and did not change the dominant perception of the lawenforcement agency. Incentives for citizens to help, cooperate with, and even monitor the police force were key points of the reform. In line with a global trend towards delegation and privatization of crime control, as well as citizens' responsibilization in this field (Garland 1996; Reeves 2017), the promotion of partnerships between citizens and the police and the "multilateralization" of providers of policing were encouraged (Bayley and Shearing 2001). As Ekaterina Khodzhaeva shows in this issue, people's volunteer squads have spread in Russia and taken various forms in local crime-fighting assemblages, intertwining law-enforcement agencies, private security companies, and citizens involved in policing (see also Khodzhaeva 2016). Passed in 2014, the Russian federal law on citizen participation in law enforcement aimed at regulating the activities of "druzhiny and Cossack units." In such a context, vigi-

7 Federal Law No. 44-FZ of April 2, 2014, On Participation of Citizens in the Maintenance of Public Order. 
lante groups may present their activity as a legitimate contribution to "governmentality" (Foucault 2004) in the field of law enforcement and policing, answering to an alleged demand from the population (Gabdulkhakov 2018). In vigilantes' view, the weakness of law enforcement agencies justifies their resort to coercion. As Ioulia Shukan shows in this issue, this is also the case in war-torn Ukraine, where vigilante groups spread during 2014-2015 in the wake of the armed conflict in Donbas. Far from the frontlines, these groups chase not only Russian proxies and "separatists" but also illegal alcohol sellers and drug dealers. Shukan shows that in the Ukrainian war context, as for instance in Northern Ireland during the Troubles (Jarman 2007), vigilantism constitutes an extension of military conflicts.

Third, in the early 2010s Russian "moral entrepreneurs" (Becker 1963) within the ruling elite launched several "crusades" (Gusfield 1963). On the one hand, the most reactionary Russian MPs, known for their attachment to values such as family or Christian Orthodox faith, promoted their agenda, leading to the passing of the 2013 law prohibiting propaganda of "nontraditional" sexual relations among minors. ${ }^{8}$ This law has contributed to legitimizing homophobic speech and practices, including those of vigilantes claiming to protect children through antipedophile activism (Favarel-Garrigues 2019). On the other hand, in order to promote a healthy lifestyle, the Russian government has strengthened the ban on alcohol consumption and smoking in public. ${ }^{9}$ The already existing legislation forbidding swearing in public places has been complemented by a law forbidding the use of mat language in public performances..$^{10}$ As the police are unable to enforce these laws, vigilante groups have found themselves new niches for the development of their activity and their popularity.

This background may help to explain how vigilantes justify their activity but not why so many volunteers are eager to take enforcement of the law in their own hands. Why do young, fit adults feel the need to go and remind people drinking in the street of the law? The question of rewards is significant here and is closely related to the importance of digital media in vigilante activity. Indeed, self-proclaimed justice makers are also YouTubers, who intend to become famous. Digital vigilantism in the Russian case is not only about patrolling the Runet, detecting and exposing suspicious behaviors on the internet-as do the kiberdruzhiny, examined by Françoise

8 Federal Law No. 135-FZ of June 29, 2013, Amendments to Article 5 of the Federal Law on the Protection of Children against Information Harmful to Their Health and Development and to Certain Legislative Acts of the Russian Federation Protecting Children from Information that Promotes the Rejection of Traditional Family Values.

9 The ban on alcohol consumption in public places has been reinforced several times, in particular in December 2013 (amendments to Article 20.20 of the Code of Administrative Offences). On the ban on smoking in public places, see Federal Law No. 15-FZ of February 23, 2013, 0n Citizens' Health Protection from Exposure to Environmental Tobacco Smoke and Consequences of Tobacco Consumption.

${ }^{10}$ Federal Law No. 101-FZ of May 5, 2014, Amendments to the Federal Law on the State Language of the Russian Federation and to Certain Legislative Acts of the Russian Federation due to Improvement of Legal Regulation in the Field of Use of the Russian Language. 
Dauce and her coauthors in this issue. It is also about finding a niche, creating and marketing content appealing to youth audiences. Vigilante shows have become a video genre, following a set of rules: for instance, the cover and title of the video must be attractive, vigilantes make efforts to prove the guilt of the alleged offender, they try to include fight scenes and humiliation scenes (Kasra 2017), while respecting some limits in the use of violence and of obscene slang, and they intend to make professional-quality movies. During the videos, leaders of the most well-known groups-Lev Protiv, Occupy Pedophilia, Davidych na Okhote (Davidych on a Hunt), for instance-act as justice makers and as presenters, commenting and justifying their deeds.

The importance given to the making of professional videos provides a clue about the kinds of benefits that vigilantes may expect. Famous leaders of vigilante groups among the youth earn an income from their activity: Mikhail Lazutin, the leader of Lev Protiv, no longer says that his raids in parks and around train stations are part of a "social project" (obshchestvennyi proekt); they are now his "work" (rabota). ${ }^{11}$ As a sponsor for the development of social projects, the Russian government subsidized three vigilante initiatives over two or three years, including Lev Protiv and StopXam (see Rashid Gabdulhakov's article in this issue). Managing three popular YouTube channels, Lazutin earns an income from the video sharing platform and also includes his own advertisements in the beginning of most of Lev Protiv's videos (FavarelGarrigues forthcoming a). Before his imprisonment in January 2014, Tesak found many ways to make money with his antipedophile "safaris": he endorsed sponsors, charged fees for participation in safaris, offered lectures and training sessions, and organized events. It should also be noted that copycat movements of the most famous groups can be found in dozens of Russian cities and in neighboring post-Soviet states (Gabowitsch 2018), as in the cases of StopXam or Occupy Pedophilia. This popularity shows that profit earned from vigilante activity is not only economic but also symbolic, enhancing the reputation of the leaders at the local level. Compared to the forms of do-it-yourself justice observed during the 2010s in other parts of the world, the tight relationships between vigilantism, YouTube shows, and profit seem peculiar to the post-Soviet space.

Variable relationships to the government are another particular feature of postSoviet vigilantism. In the United States vigilante groups have often been driven by local elites-wealthy white males-denouncing the failure of federal policies and protecting the "established order" (Rosenbaum and Sederberg 1974). In Europe the far-right milieu gives birth to antimigrant groups (Fekete 2017). In Russia, at least in the mid-2010s, vigilante groups have attracted young urban activists sharing a taste for fighting techniques and for YouTube shows, but promoting very diverse political attitudes and beliefs among Russian youth, from proregime patriots to neo-Nazi activists. Grichishkin, the leader of the Youth Antidrug Commando, has, for instance, presented himself as a pro-Putin patriot, joining the ranks of the anti-Maidan move-

${ }^{11}$ See for instance an interview with Lazutin: Nikita Zabaznov, “Lev protiv /Mikhail Lazutin/ na interv'iu s kolkhoznikom," posted October 7, 2017. Video, 42:04. https://youtu.be/50RGJSC6C9U. 
ment in January $2015 ;^{12}$ denouncing US attempts to influence Russian politics, the Movement for National Liberation (NOD) has targeted associations officially labeled as "foreign agents." ${ }^{13}$ In these cases the autonomy and spontaneity of these groupswhich are considered key features of vigilantism in the classic definition-are questionable. On the contrary, Tesak or 0ccupy Pedophilia's regional leaders do not support the current regime and share neo-Nazi ideological beliefs and are therefore considered "extremists" according to the law. As a result, the attitude of law-enforcement bodies toward vigilante groups ranges from official sponsorship to covert support to repression (Favarel-Garrigues forthcoming b). Finally, it should be noted that government support for each group varies over time, as illustrated by the StopXam case presented in this issue. The legitimacy of the means employed to enforce the law constitutes a permanent source of negotiation and of discussions between vigilante groups, law-enforcement agencies, and the government more generally.

How to study vigilante groups? Despite the development of these groups in the post-Soviet space during the 2010s, few researchers deal with this issue. What we know about vigilantism comes mostly from the press. Thanks to journalists' investigations, some of the groups were analyzed at their beginning ${ }^{14}$ or at their peak. ${ }^{15}$ The task remains particularly challenging for researchers in the social sciences. First, these groups are closed and suspicious of outsiders, because they use illegal means to reach their goals, or their aim is to make money, or law-enforcement agencies target them as "extremists" or "hooligans," as in the case, for instance, of some skinhead gangs involved in antipedophilia activism. Second, these groups place researchers in a painful moral dilemma of choosing the "good" side between alleged pedophiles and their skinhead hunters, between drug dealers and their violent attackers, between a moral or national community's enemies and its vigilant defenders. Third, from an ethical point of view, working on vigilantism necessarily gives resonance to vigilante projects themselves, as well as to vigilante groups' leaders, who, claiming to defend a just cause, never remain anonymous. Moreover, such projects appreciate all forms of visibility as they endeavor to promote, as all entrepreneurs do, their brand. Consequently, researchers working on these groups have to be aware that they contribute inevitably to vigilantes' marketing strategy, although this does not mean that they need to anonymize widely known vigilantes' names.

12 See for instance an interview with Grichishkin as an "Anti-Maidan movement activist": “Lidery dvizheniia 'Antimaidan' proveli pervuiu publichnuiu aktsiiu," 5-i kanal, February 16, 2015. http://www.5-tv.ru/news/94187.

13 See for instance NOD's actions against the Memorial Society: "Massovyi piket Za pravdu 0 chechenskoi voine, protiv deiatel'nosti obshchestva 'Memorial,'” NOD, March 16, 2016. http://rusnod.ru/aktsii-nod/2016/03/16/aktsii-nod_7633.html.

14 On Lev Protiv, see Mariia Sher, “Pravookhranitel'naia samodeiatel'nost': Chem opasny dobrovol'nye bortsy s narushiteliami poriadka." Kommersant Den'gi, September 21-27, 2015 (no. 37), 21-25. On Sorok Sorokov, see Daniil Turovskii, "Stroiteli offlain-gosudarstva," Meduza, September 22, 2015. https://meduza.io/feature/2015/09/22/stroiteli-oflayn-gosudarstva.

15 On Occupy Pedophilia, see Daniil Turovskii, "Belaia sotnia: Nasledniki Tesaka." Meduza, October 20, 2014. https://meduza.io/news/2014/10/20/belaya-sotnya-nasledniki-tesaka. 
While this thematic issue of Laboratorium on vigilantism presents a variety of methodological approaches, including media content analysis, semistructured interviews, remote follow-up of vigilante activities on social networks, and even ethnographic observation, some general suggestions may be drawn. First, as vigilantism requires being visible and relies heavily on communication, its various communication products (leaders' statements, groups' official communiqués, video or photo accounts of actions, etc.), distributed largely on social networks, need to be taken seriously. They are, of course, legitimation arguments and a response to vigilantes' desire to master their groups' public image by letting various publics see only partial reality. At the same time, they are also a good way of getting a sense of vigilantes' practices, their perceptions concerning their targets, their views on legitimate means of action, and their justification for the use of coercion.

Second, public controversies and debates surrounding vigilantism-as opportunities for different social actors to question vigilantes' dominant beliefs, representations, practices, especially those about which vigilantes remain more discreet, as well as vigilante groups' inscription in power relations - can be a valuable source for analyzing vigilantism. As a "social interaction likely to have an audience" (Lemieux 2007:194), controversy leads the public to judge the relevance of the arguments of conflicting protagonists. The judgment depends on the identity of the accusers, on the relevance of the accusations, and on the robustness of vigilantes' self-justifications. The accusers correspond to diverse social identities, starting with the victims of the groups, who voice their feelings on social media and sometimes try to organize collective mobilizations against vigilantes. Former members of a vigilante group might also voice their disappointment in the leader or group's activities and even reveal some hidden aspects of the organization. Moreover, the public expresses its feelings in the comments sections of the platforms that offer the videos. Finally, on a more professional level, human rights activists, journalists, lawyers, politicians, and law-enforcement agencies are the main voices of criticism of vigilante groups.

The four main controversial issues regarding vigilantes concern their rewards and profit, the legality of their methods, the results they obtain and the efficiency of their actions, and their legitimacy to act as role models for youth: are they heroes or hooligans, justice makers or troublemakers? Some expressions employed to criticize them also reveal debates about their role in maintaining political order, for instance komsomol'tsy (former Communist Party Youth Organization), timurovtsy (inspired by an Arkadii Gaidar novel about a group of young adolescents fighting crime in the Soviet Union), or khunveibiny (the Chinese Red Guards during the Cultural Revolution).

Finally, ethnographic observations, even if limited, are sometimes also possible to conduct, and they are especially useful for grasping the practices of vigilantism and the reactions they provoke on the streets. Indeed some vigilantes' actions are public - they regularly take place in parks, like Lev Protiv in Moscow, for instanceand can be directly observed. Other actions are carried out with more discretion and the researcher needs to be granted entry to the group through the recommendation of a group member or be authorized to follow the group's activities by its leader, as in 
the case of some groups examined by Ioulia Shukan in this issue. In these cases, when researchers are introduced to and permitted to follow the group, they might even be seen as a resource for the group's communication strategy, as potential useful witnesses able to disseminate information about vigilantes' deeds and thus potentially enhance their reputation.

This issue of Laboratorium brings together four case studies of post-Soviet vigilantism and citizens' participation in law enforcement. In his qualitative analysis of the traditional media coverage of StopXam (Stop a Douchebag), a vigilante group specializing in the denunciation and media exposure of parking offenders, Rashid Gabdulhakov addresses the question of media framing of vigilantism on Russian TV channels (Channel One, NTV, REN TV, Rossiia 24, and TV Rain). The author argues that, by granting voice to StopXam vigilantes and exposing their targets to wider audiences, the traditional media, like digital media, increase the cost of parking violations and thus help vigilantes to weaponize visibility. Gabdulhakov also shows how much StopXam's portrayal by Russian TV channels was dependent on the authorities' attitudes toward the group and in line with unspoken rules about what can and cannot be said on national television. In the early stages, when StopXam benefited from the government's informal endorsement, all broadcasters depicted its members positively as "activists" or "concerned citizens" and referred to the group itself as a "public movement" or an "NG0." They also contributed to shaming StopXam's targets by framing women offenders through their physical features (referring to female targets as "the blonde" or "a fragile gal"), through referencing their social status ("rich and powerful," politicians, celebrities), as well as by describing their vehicles as "expensive." Only after the scandal that opposed StopXam to a prominent Russian athlete in 2016 and a subsequent shift in the government's position on StopXam did news reports start to question the real motives of StopXam vigilantism and accuse the group of being profit driven and state sponsored.

In their article on digital vigilantism in Russia in the context of tighter state regulation of Runet and delegation of security issues to civil society through government-sponsored programs, Françoise Daucé, Benjamin Loveluck, Bella Ostromooukhova, and Anna Zaytseva analyze citizens' involvement in cyber surveillance and distinguish two different models of vigilantism. On the one hand is the model of online "citizen investigators" developed by Molodezhnaia Sluzhba Bezopasnosti (MSB, Youth Security Service) since the early 2000s that refers to online monitoring of and reporting on illicit online content (drug addiction, child pornography, "extremism," etc.) by professionals specialized in emerging cyber offenses. On the other hand is the model of "cyber patrols" that relies on a day-to-day low-intensity surveillance of illicit content online by amateurs recruited among the young and trained by Liga Bezopasnogo Interneta (LBI, Safe Internet League). The authors argue that both models of digital vigilantism-professional and amateur-imply cooperation with monitoring state agencies (Roskomnadzor, the Ministry of Internal Affairs, the Prosecutor General's Office, and the Federal Security Service), as well as with social media administrators, and are part of a new "public-private security assemblage" applied to Runet. Both groups also develop a pragmatic relationship with legality, acting in gray 
areas, even if shifts in legal procedure constrain their activities more and more. They take, however, an opposite stand on politics and principles of digital vigilantism, as revealed, in particular, by debates around the cyber-patrol bill in 2018. MSB refuses to go beyond their professional technical expertise in cyber child protection and denounces the risk of political use of new cybersecurity agents. LBI is actively involved in the promotion of patriotism and good conservative morals among the young, including Cossack values in the case of their sub-project of "Cossack cyber patrols."

In her ethnographic case study of vigilante groups in Odesa, Ioulia Shukan grasps wartime vigilantism in Ukraine. This phenomenon gained ground as a result of the ongoing war in Donbas with a consequential radical redeployment of the Ukrainian state, an increase in the value of private paramilitary resources, and a (re) distribution of violence between state and nonstate actors. First, through an analysis of vigilantes' social background and dominant representations, the author argues that vigilantism in Odesa has attracted mainly four social profiles (businessmen, former combatants or security officers, far-right activists, and the young), relies heavily on coercion, and implies an intense socialization of vigilantes' physical bodies into the use of weapons and combat sports. Second, through an analysis of vigilantes' three main social roles-national community guards, patrolling agents, and justice makers - the author points to utter confusion in vigilantes' deeds between disinterested promotion of public good (security, order, justice) and satisfaction of private interests. The article also shows that given the scarcity of resources at their disposal and the near-absence, unlike in Russia, of state sponsorship, Odesa's vigilantes maintain a complex relationship with local political and economic elites, ranging from exchanges of services to direct confrontations. Shukan points out that, even if the war has provided vigilantism with wide social recognition as a necessary and acceptable response to the armed conflict and its hybrid threats, controversies around vigilantism as a challenge to Ukrainian law-enforcement agencies have nevertheless spread.

In her sociohistorical analysis of the dobrovol'nye narodnye druzhiny (DNDs, people's volunteer squads) and their organizational principles in Russia before and after the adoption of the 2014 Russian Federal Law No. 44-FZ On Participation of Citizens in the Maintenance of Public Order, Ekaterina Khodzhaeva explores the frontier between vigilantism and state-sponsored citizens' participation in law enforcement. Indeed, even if DNDs are closer to auxiliary police agents than to vigilantes, they contribute as citizens, usually on a voluntary basis, to policing missions. The author shows that, in the 2000s, when Russian authorities rediscovered and reinvested in Soviet institutions and practices including DNDs, three models of top-down citizens' involvement in security provision and thus of "private-public security assemblages" were observed on the streets at the regional level. First is a centralized model of citizens' mobilization for DNDs, where regional authorities initiated the renaissance of people's guards and entrusted them with law-enforcement activities (joint patrols, traffic regulation, etc.) under tight control of the police. Second is a noncentralized model, where big local industries participated in DNDs' formation by stimulating 
workers' participation in street patrols and by financing their activities. Third is an ad hoc model, where DNDs appeared as a response-and sometimes a result of citizens' self-organization-to a temporary increase in criminality or to a violent crime. Khodzhaeva argues then that the 2014 law on citizens' participation in law enforcement, adopted two years after a radical police reform and a drastic reduction of police personnel, largely contributed to the homogenization of DNDs' organizational principles, often breaking with previous regional traditions. The new centralized DND's organizational model implies a tighter control of squads by the Ministry of Internal Affairs in charge of their members' training and scheduling of their patrols, as well as by regional administrations responsible for financing their activities. It also entails an intensification of citizens' top-down mobilization with distribution to low-level police officers of quotas to fulfill (number of DNDs and conducted patrols, recruitment quotas), which contradicts the very principle of voluntary participation of citizens in DNDs. The new model, finally, relies on a set of rewards offered to squad members that go from salaries to material advantages through social benefits.

\section{REFERENCES}

Abrahams, Ray. 1998. Vigilant Citizens: Vigilantism and the State. Oxford: Polity Press.

Bayley, David H., and Clifford D. Shearing. 2001. The New Structure of Policing: Description, Conceptualization, and Research Agenda. Research Report, National Institute of Justice. Washington, DC: US Department of Justice. https://www.ncjrs.gov/pdffiles1/nij/187083.pdf.

Becker, Howard S. 1963. Outsiders: Studies in the Sociology of Deviance. New York: Free Press of Glencoe.

Brown, Richard Maxwell. 1975. Strain of Violence: Historical Studies of American Violence and Vigilantism. New York: Oxford University Press.

Favarel-Garrigues, Gilles. 2019. "Digital Vigilantism and Anti-Paedophile Activism in Russia: Between Civic Involvement in Law Enforcement, Moral Policing and Business Venture." Global Crime. doi:10.1080/17440572.2019.1676738.

Favarel-Garrigues, Gilles. Forthcoming a. "Criticism of Moral Policing in Russia: Controversies around Lev Protiv in Moscow." In Vigilant Audiences, ed. by Daniel Trottier. Cambridge: Open Book Publishers.

Favarel-Garrigues, Gilles. Forthcoming b. "Vigilante Shows and Law Enforcement in 2010s Russia." Europe-Asia Studies.

Fekete, Liz. 2017. Europe's Fault Lines: Racism and the Rise of the Right. London: Verso.

Foucault, Michel. 2004. Security, Territory, Population: Lectures at the Collège de France 1977-1978, trans. by Graham Burchell. New York: Picador.

Fourchard, Laurent. 2018. Trier, exclure, policer: Vies urbaines en Afrique du Sud et au Nigéria. Paris: Presses de Sciences Po.

Frank, Stephen P. 2000. Crime, Cultural Conflict, and Justice in Rural Russia, 1856-1914. Berkeley: University of California Press.

Frierson, Cathy. 1987. “Crime and Punishment in the Russian Village: Rural Concepts of Criminality at the End of the Nineteenth Century." Slavic Review 46(1):55-69.

Gabdulhakov, Rashid. 2018. "Citizen-Led Justice in Post-Communist Russia: From Comrade Courts to Dotcom Surveillance." Surveillance and Society 16(3):314-331.

Gabowitsch, Mischa. 2018. "Are Copycats Subversive? Strategy-31, the Russian Runs, the Immortal Regiment, and the Transformative Potential of Non-Hierarchical Movements." Problems of Post-Communism 65(5):297-314. doi:10.1080/10758216.2016.1250604.

Garland, David. 1996. "The Limits of the Sovereign State: Strategies of Crime Control in Contemporary Society." British Journal of Criminology 36(4):445-471. 
Gerber, Theodore P., and Sarah E. Mendelson. 2008. “Public Experiences of Police Violence and Corruption in Contemporary Russia: A Case of Predatory Policing?" Law \& Society Review 42(1):144.

Gusfield, Joseph R. 1963. Symbolic Crusade: Status Politics and the American Temperance Movement. Urbana: University of Illinois Press.

Jarman, Neil. 2007. "Vigilantism, Transition and Legitimacy: Informal Policing in Northern Ireland." Pp. 319-347 in Global Vigilantes, ed. by David Pratten and Atreyee Sen. London: Hurst.

Johnston, Les. 1996. “What Is Vigilantism?” The British Journal of Criminology 36(2):220-236.

Kasra, Mona. 2017. “Vigilantism, Public Shaming, and Social Media Hegemony: The Role of DigitalNetworked Images in Humiliation and Sociopolitical Control." The Communication Review 20(3):172-188. doi:10.1080/10714421.2017.1343068.

Khodzhaeva, Ekaterina. 2016. Lokal'nye initsiativy okhrany obshchestvennogo poriadka v Rossii: Ot narodnykh druzhin do munitsipal'noi militsii. Anatilichestkii otchet. Moscow: Tsentr strategicheskikh razrabotok. https://csr.ru/wp-content/uploads/2016/12/Report-25.10.2016.pdf.

Laryš, Martin, and Miroslev Mareš. 2011. "Right-Wing Extremist Violence in the Russian Federation." Europe-Asia Studies 63(1):129-154. doi:10.1080/09668136.2011.534308.

Lemieux, Cyril. 2007. "A quoi sert l'analyse des controverses?" Mil neuf cent: Revue d'histoire intellectuelle 25(1):191-212.

Moncada, Eduardo. 2017. "Varieties of Vigilantism: Conceptual Discord, Meaning and Strategies." Global Crime 18(4):403-423. doi:10.1080/17440572.2017.1374183.

Reeves, Joshua. 2017. Citizen Spies: The Long Rise of America's Surveillance Society. New York: New York University Press.

Roizman, Evgenii. 2005. Gorod bez narkotikov. Yekaterinburg, Russia: Self-Published.

Rosenbaum, H. Jon, and Peter C. Sederberg. 1974. “Vigilantism: An Analysis of Establishment Violence." Comparative Politics 6(4):541-570.

Sen, Atreyee, and David Pratten. 2007. "Global Vigilantes: Perspectives on Justice and Violence." Pp. 1-24 in Global Vigilantes, ed. by David Pratten and Atreyee Sen. London: Hurst.

Shnirel'man, Viktor. 2011. Porog tolerantnosti: Ideologiia i praktika novogo rasizma. Vol. 2. Moscow: Novoe literaturnoe obozrenie.

Taylor, Brian D. 2011. State Building in Putin's Russia: Policing and Coercion after Communism. New York: Cambridge University Press.

Trottier, Daniel. 2017. "Digital Vigilantism as Weaponisation of Visibility." Philosophy and Technology 30(1):55-72. doi:10.1007/s13347-016-0216-4. 